\title{
HISTÓRIA EM QUADRINHOS: UMA ESTRATÉGIA METODOLÓGICA NO PROCESSO DE ENSINO E DE APRENDIZAGEM DA LEITURA E DA ESCRITA
}

\section{INTRODUÇÃO}

\author{
Antonia Dalva França-Carvalho ${ }^{1}$ \\ Dafne Barros Araújo ${ }^{2}$ \\ Jucyelle da Silva Sousa ${ }^{3}$ \\ Mayara Monteiro Andrade ${ }^{4}$
}

$\mathrm{O}$ ato de ler, em princípio foi caracterizado como um processo de decodificação de uma língua, isto é, era considerada como a decifração de signos, transformando-os em oralidade. Neste aspecto, se confunde oralização, leitura e leitura em voz alta (ORLANDI, 2006). Entre 1960 e 1970, segundo Foucambert (1994), a escola confrontou-se com um problema de leitura que não conseguiu superar. Uma vez evidenciada sua complexidade que não mais a reduzia a mera decodificação de palavras, a leitura passa ter outro sentido. Este sentido se refere ao contexto sociocultural ao qual estamos imersos, carregado de sentidos e significados, muitas vezes desconhecidos, mas que coloca o leitor na posição de intérprete daquilo que lê.

Ler e escrever, portanto, são processos interconexos. Porém, a compreensão de que a escrita representa uma sequência fonológica (o significante) e não diretamente o significado das palavras, não é tarefa fácil para as crianças (NUNES, 1992), por exigir uma ação de análise difícil, sobremodo para a faixa etária préescolar. Porém, não é impossível. Pesquisas (FERREIRO 2001; TEBEROSKY,1985; TEBEROSKY, 1992; SILVA,1993) têm confirmado que a escola pode influenciar a criança a pensar sobre as palavras no decorrer do processo ensino-aprendizagem da leitura e da escrita, considerando sua capacidade

\footnotetext{
${ }^{1}$ Doutora em Educação. Professora do Programa em Pós-Graduação em Educação da UFPI e do Departamento de Fundamentos da Educação, do Centro de Ciências da Educação, da Universidade Federal do Piauí. Presidente da Comissão de Governança dos Programas de Formação Inicial de Professores, da Universidade Federal do Piauí. Líder do Núcleo Interdisciplinar de Pesquisas em Educação e Epistemologia da Prática Profissional (NIPEEPP). E-mail: adalvac@uol.com.br.

2 Graduada em Licenciatura em Pedagogia, pela Universidade Federal do Piauí. Email: dafneab@hotmail.com

${ }^{3}$ Mestre em Educação. Professora da Educação Básica. Pesquisadora do Núcleo Interdisciplinar de Pesquisas em Educação e Epistemologia da Prática Profissional (NIPEEPP). Email: ju-cy13@hotmail.com

${ }^{4}$ Graduada em Licenciatura em Pedagogia, pela Universidade Federal do Piauí. Graduanda em Fisioterapia, pela Universidade Estadual do Piauí. Email: myalamonteiro@hotmail.com
} 
intelectual (como sujeito), de interagir com o objeto (a língua), mediante orientação do professor. Apontam também que o sucesso depende da qualidade das atividades desenvolvidas, para conduzir o sujeito (a criança) a testar suas hipóteses e, a partir de uma ação inteligente, constatá-las.

Porém, a escola na acepção de Speroni (2010) ainda prefere explorar a língua escrita sem apelar para memória visual, centralizando seu ensino no domínio de um código de correspondência muito aproximativo. E é neste sentido que a autora sugere que as práticas educativas de leitura dos professores devam possibilitar aos alunos, meios eficazes para que se tornem agentes construtores de suas aprendizagens, descobridores de um mundo de vida com significações concretas.

Considerando as dificuldades de leitura existentes entre alunos da educação básica do ensino fundamental, enfrentadas por alunos do $4^{\circ}$ ano de uma escola pública onde desenvolvemos o projeto Pibid $^{5}$ e Prodocência $^{6}$, questionamos sobre as práticas utilizadas pela professora e buscamos uma forma de colaborar para minimizar essas dificuldades encontradas.

\begin{abstract}
É útil se perguntar através de que tipo de práticas a criança é introduzida na língua escrita, e como se apresenta este objeto no contexto escolar. Há práticas que levam a criança a pensar que o conhecimento é algo alheio, sem nunca ser participantes na construção do conhecimento. Há práticas que levam a pensar que "o que existe para se conhecer" já foi estabelecido como um conjunto de coisas fechado, sagrado, imutável e não modificável. Há praticas que levam o sujeito (a criança neste caso) a ficar de "fora" do conhecimento como expectador passivo ou receptor mecânico, sem nunca encontrar respostas aos "porquês" e aos "para quês" que já nem sequer se atreve a formular em voz alta. (FERREIRO, 2001, p.45)
\end{abstract}

Observada a realidade da turma procuramos encontrar soluções simples, de fácil acesso e concretas para incluir esses alunos no processo de construção do conhecimento. Baseados nessa perspectiva é que nos sentimos instigados a procurar, buscar e conhecer para transformar esse ambiente que muitas vezes não sabe lidar com essas dificuldades de aprendizagem. Assim, nos propomos a trabalhar uma estratégia de ensino tomando as Histórias em Quadrinhos (HQs). Os gibis possuem características próprias e são, há muito tempo, conhecidos e aceitos

\footnotetext{
5 Programa Institucional de Bolsa de Iniciação à Docência

${ }^{6}$ Programa de Consolidação das Licenciaturas
} 
pela população, por serem histórias breves, bem humoradas, com imagens, instigando a imaginação não só das crianças, como também dos adultos.

Levando em consideração o encantamento das crianças para com esse tipo de livro, procuramos entender quais as vantagens de trabalhar esse recurso em sala de aula como auxílio no processo de leitura e escrita dos alunos. A ideia foi demonstrar que mesmo com o desinteresse dos alunos pela leitura, frequentemente percebida nos dias atuais, é possível que o professor desperte a atenção e o gosto dessas crianças, utilizando esse material simples que, quando bem utilizado, transforma-se numa poderosa ferramenta de auxílio pedagógico. Com efeito, Luyten (2011, p.56) afirma que:

As histórias em quadrinhos motivam até os alunos relutantes ao aprendizado e à leitura, pois elas os envolvem num formato literário que eles conhecem. E também "falam" com eles de uma forma que entendem e, melhor do que isto, se identificam. Mesmo para os alunos que já estão com o hábito de leitura formado.

A importância dos gibis também é destacada nos Parâmetros Curriculares Nacionais da Língua Portuguesa, reforçando a ideia de que os mesmos podem e devem ser utilizados em sala de aula, pois podem contextualizar a aprendizagem da língua; também é explicitada a importância de que sejam colocados à disposição dos alunos nas bibliotecas das escolas, para que estes tenham contato com todos os tipos de gêneros textuais (PCN, 1997).

Neste sentido, o presente trabalho ${ }^{7}$ foi desenvolvido com alunos do $4^{\circ}$ ano do Ensino Fundamental, da escola de tempo integral CETI Professor Darcy Araújo, localizada na cidade de Teresina, no estado do Piauí. Para efetuarmos nossa pesquisa fizemos uma intervenção pedagógica no decorrer de cinco dias. Neste ínterim, levamos histórias em quadrinhos e, dentre a variedade de HQs existentes, selecionamos as histórias da Turma da Mônica para trabalhar com a classe. A escolha decorre da compreensão de que as HQs caracterizam-se como um recurso didático ou uma estratégia de ensino que se distingue dos procedimentos mecânicos leitura e de escrita. Nestes procedimentos, na acepção de Silva (1993), não há

\footnotetext{
${ }^{7}$ Este artigo possui sua versão original publicada na obra FRANÇA-CARVALHO, A. D.; MARTINS, C. H. R.; CONDE, E. P.; MONTEIRO, H. R. de S. (org.) Estratégias de ensino: propostas multidisciplinares de aprendizagens significativas. Teresina, EDUFPI, 2013.
} 
esforço para compreensão do sistema da escrita, cuja consequência é um avanço mais lento ou mesmo uma estagnação do nível em que se encontram as crianças.

Neste aspecto, esclarecemos que o presente trabalho é produto de uma investigação de abordagem qualitativa, do tipo interventivo, que procurou buscar respostas para uma questão particularizada e expressar estas respostas de modo qualitativo, evidenciando a modificação de uma realidade. Com efeito, a pesquisa qualitativa se preocupa com um nível de realidade que não pode ser quantificado, ou seja, ela trabalha com o universo de significados, motivos, aspirações, crenças, valores e atitudes, o que corresponde a um espaço mais profundo das relações dos processos e dos fenômenos que não podem ser reduzidos a operacionalização de variáveis. (MINAYO, 2000). Assim, através da observação das estratégias de ensino da leitura e da escrita utilizadas no lócus investigado, efetuamos uma intervenção pedagógica por meio do uso das HQs, como estratégia lúdica e diversificada de desenvolvimento cognitivo, afetivo e psicomotor, tomando a escrita e a leitura como pano de fundo. Trata-se, portanto, de uma perspectiva sistematizada de qualificar a ação pedagógica e de aproximar a teoria e a prática, podendo ser caracterizada como pesquisa-ação. Além do que, a pesquisa-ação Para Nunan (1993 apud Engel, 2000) constitui um meio de desenvolvimento profissional intrínseco, pois parte das preocupações e interesses das pessoas envolvidas na prática.

\section{A UTILIZAÇÃO DAS HQS COMO ESTRATÉGIA DIDÁTICO-PEDAGÓGICA NO PROCESSO ENSINO- APRENDIZAGEM}

A literatura aponta que as histórias em quadrinhos podem se tornar uma importante ferramenta de ensino e de aprendizagem, quando bem utilizada. Neste caso, é preciso que o professor responsável se familiarize com o trabalho que desenvolverá e busque estratégias inovadoras que possibilitem um maior aprendizado para os alunos. Em geral, os quadrinhos possuem temas educativos e interessantes que despertam o interesse do público. Além disso, também podem ser utilizados em diferentes disciplinas e não apenas em Língua Portuguesa, como muitos pensam.

Nesta perspectiva, é importante que o professor não tenha a visão reducionista de que basta entregar essas histórias e pedir que os alunos apenas leiam. Ele precisa ir além e desenvolver táticas para que o aluno se interesse e sinta 
vontade/ necessidade de buscar outros tipos de literatura, bem como propor instrumentos facilitadores para que o aluno se aproprie do conhecimento. Segundo Anastasiou e Alves (2003, p.77),

[...] através das estratégias aplicamos ou exploramos meios, modos, jeitos favoráveis para executar ou fazer algo. Esses meios ou formas comportam determinadas dinâmicas, devendo considerar o movimento e as forças e o organismo em atividade.

Para tanto, o professor precisa de um elemento muito importante: a criatividade que se encontra inserida no cotidiano escolar, através das relações interpessoais, e está relacionada ao compromisso e à competência do mesmo. Pode ser entendida tanto como um ato ou uma ação espontânea, um modo de expressão que se constitui por várias vezes em determinados ambientes, permitindo que o sujeito desenvolva uma ação de estímulos, sinalizando o esforço sensível, inteligente e enriquecedor, fazendo com que viva a sua própria história em seu tempo e contexto. (MELO, 2007).

Outro aspecto importante a ser ressaltado refere-se à escolha do gibi que será utilizado. Hoje, no Brasil, existe uma infinidade de possibilidades. Por isso, é interessante, quando se trabalha com crianças, escolher histórias que elas se identifiquem e possam lhe trazer algum significado, por exemplo, utilizar quadrinhos com personagens infantis, pois provavelmente elas encontrarão nessas histórias experiências já vivenciadas no seu cotidiano. Nesta hora de escolha, as ilustrações também não podem ser esquecidas, já que estas também assumirão o papel de linguagem, no caso a não-verbal. De acordo com Sousa (2012), a imagem, muitas vezes, assume o papel do texto e a mesma deve ser desvendada, interpretada e compreendida. Levando em consideração esse aspecto, evidencia-se que deve haver harmonia entre o texto e as imagens, a fim de que o conjunto faça sentido ao leitor.

Portanto, para que o professor desperte nos seus alunos o interesse pela leitura e escrita através dos gibis, é preciso que defina e busque metodologias adequadas para o desenvolvimento do seu trabalho, em razão de que estas podem contribuir no incentivo à formação de futuros leitores e escritores, bem como auxiliálos no decorrer do processo educativo em geral. 


\section{PROJETO DE HQs: METODOLOGIA}

Como dito anteriormente, utilizamos as HQs da Turma da Mônica e no decorrer de cinco dias realizamos um projeto com alunos do $4^{\circ}$ ano do Ensino Fundamental. Em princípio, nos apresentamos à turma e esclarecemos o que seria trabalhado com eles ao longo da semana, para então explicar sobre as histórias em quadrinhos. Indagamos se eles conheciam as HQs, o que eles achavam e se sabiam ler esse tipo de livro. Explicamos como é importante o contato com a leitura não só dos gibis, como também de outras literaturas. Preparamos uma cesta com vários bonecos da Turma da Mônica e gibis e levamos para a sala de aula no primeiro dia, para que os alunos despertassem a curiosidade, criassem expectativas pelas atividades que seriam realizadas e brincassem, a fim de proporcionar ludicidade à prática pedagógica, pois como afirma Freitas e Salvi (2007, p.99),

No processo de ensino-aprendizagem as atividades lúdicas ajudam a construir uma práxis emancipadora e integradora, ao tornarem-se um instrumento de aprendizagem que favorece a aquisição do conhecimento do educando.

No segundo dia, dividimos a sala em quatro grupos e entregamos um gibi para cada aluno. As monitoras ficaram responsáveis por três grupos e a professora da sala também ficou com um. Diante dos gibis, cada grupo selecionou uma única história para ser lida entre todos.

Figura 1 - Cesta de HQs.

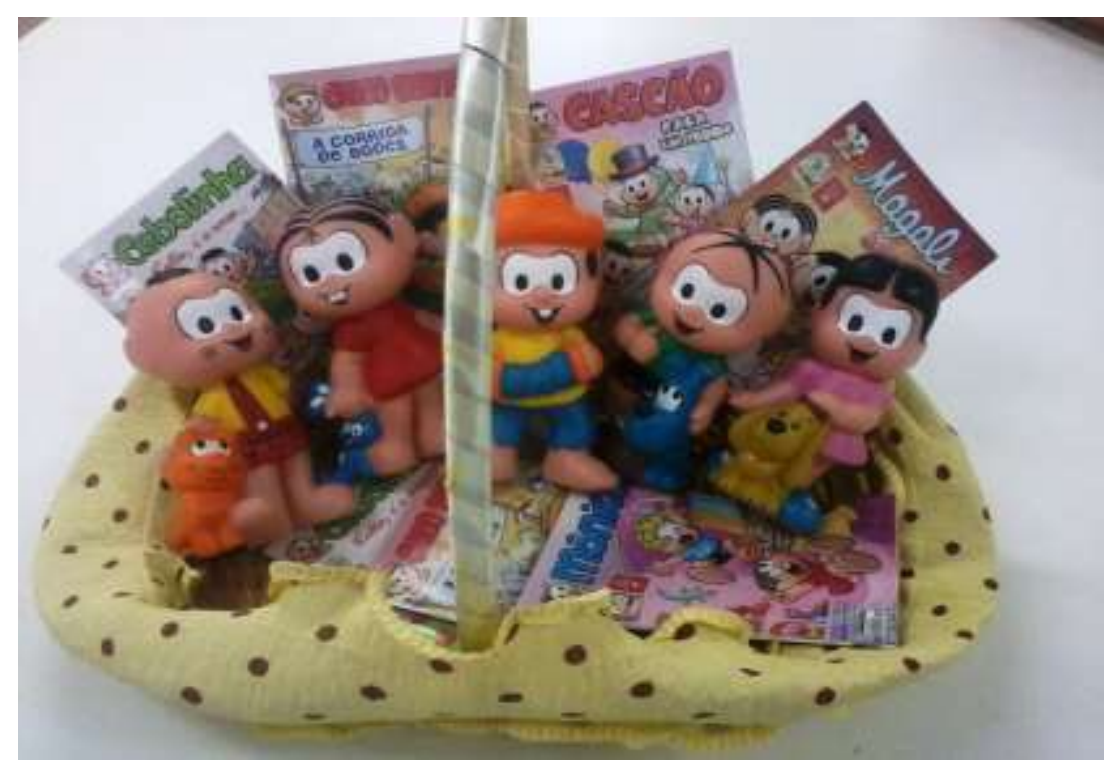

Fonte: As autoras. Teresina, 2013. 
Após lermos a história, solicitamos aos alunos que recontassem a mesma da forma que entenderam e depois ilustrassem de acordo com sua criatividade, pois entendemos que o espírito inventivo, remete à consciência de singularidade no ser humano, é nela onde a pessoa se expressa, faz suas escolhas estabelecendo suas relações, descobrindo suas possibilidades de agir.

Figura 2 - Momento de apresentação dos bonecos e da leitura das histórias selecionadas.

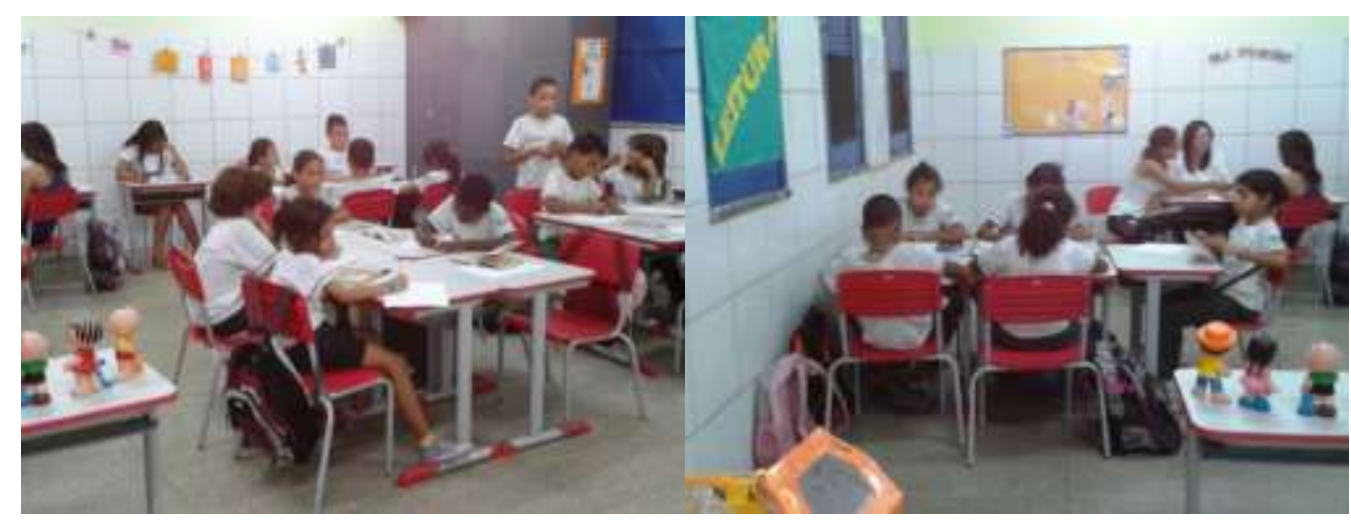

Fonte: As autoras. Teresina, 2013.

Figura 3 - Momento em que as histórias foram recontadas e ilustradas.

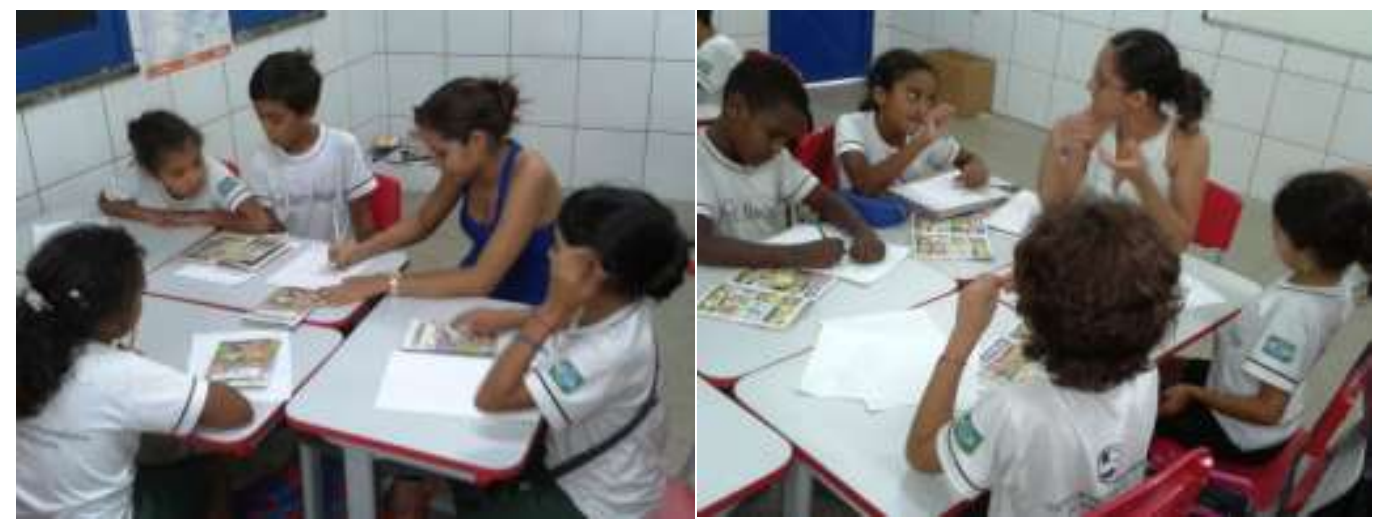

Fonte: As autoras. Teresina, 2013. 
Figura 4 - Ensaio das histórias.

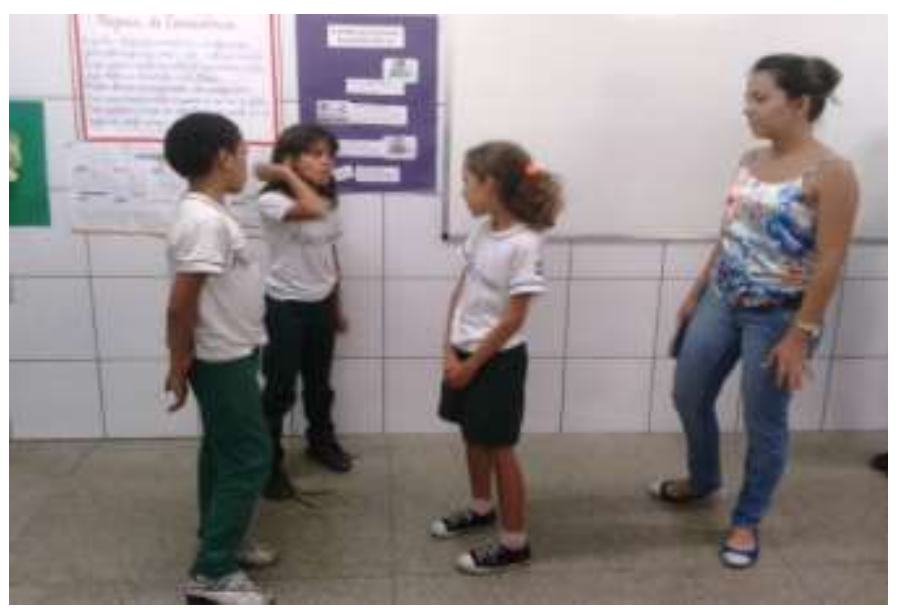

Fonte: As autoras. Teresina, 2013.

$\mathrm{Na}$ recontagem das histórias, as produções dos alunos sinalizaram que a maioria se encontra em um nível de escrita avançado, pois conseguem interpretar os textos, bem como identificar a voz do narrador e das personagens. É importante ressaltar que nem todos os alunos da turma estão no mesmo nível de desenvolvimento, pois alguns confundem algumas palavras, apresentam dificuldade na leitura, sendo comum os erros ortográficos.

Figura 5 - Produção de uma aluna.

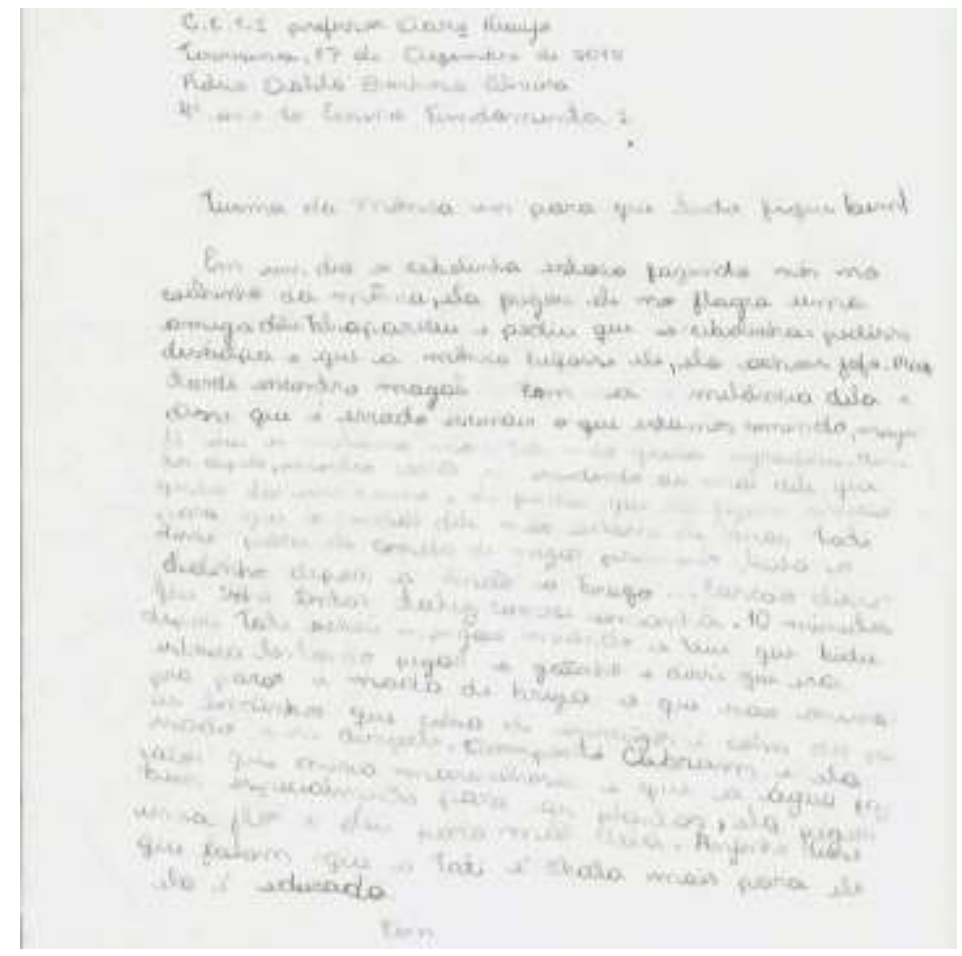

Fonte: Dados da Pesquisa. Teresina, 2013. 
Figura 6 - Produção de uma aluna.

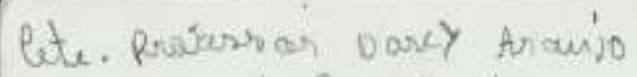

Tersina 17 de Desumbro de 2012.

Gumolas tima elesa,

$$
\text { cocoricóó!!! }
$$

De manhà udo thico Bento Ancardausam a quela enorma Ruquicat

Foi tirar lette da vaca, dar matha para as galimhas,

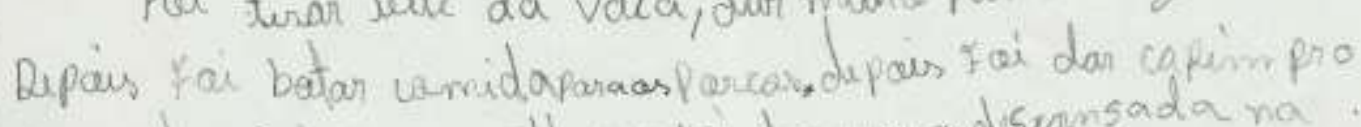

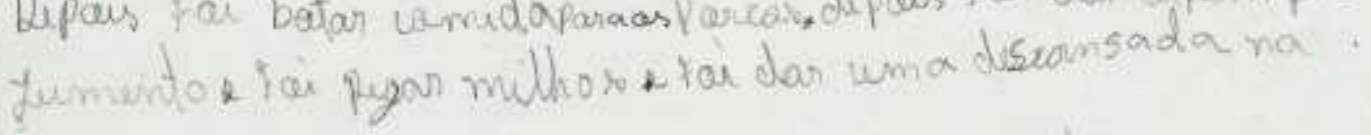
arviere.

Parraur uro hamem a dirse esse pesesoalé mesmo muito

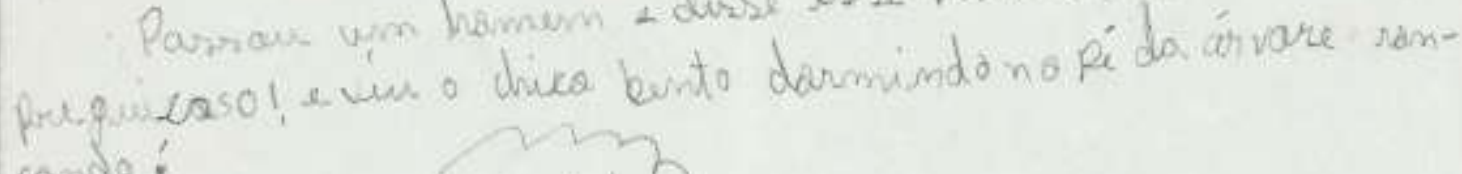
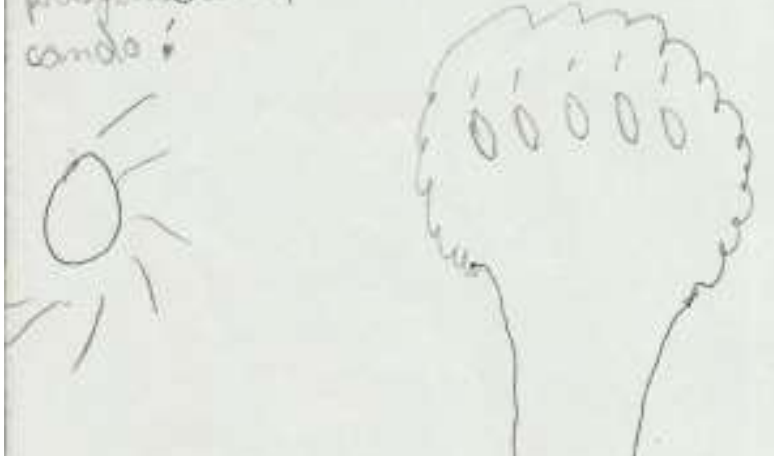

minnower

nim

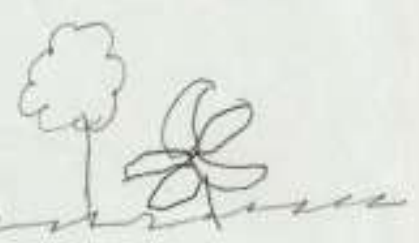

Fonte: Dados da Pesquisa. Teresina, 2013. 
Figura 7 - Produção de uma aluna.

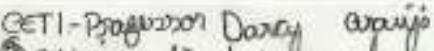

Ouresina, 17 de Direnlog de 2012

CEbala em otonum Reabisado

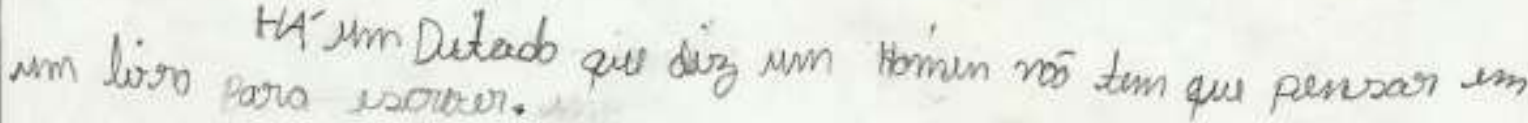

Lirro mas dia o papai do sebalinta ustava tentonado ezouver um

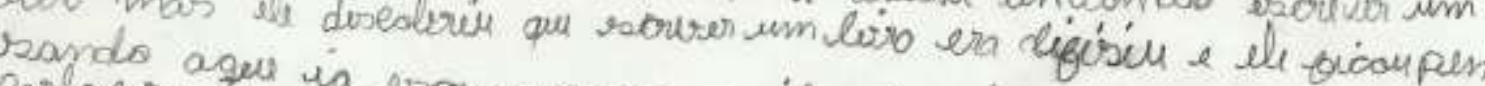

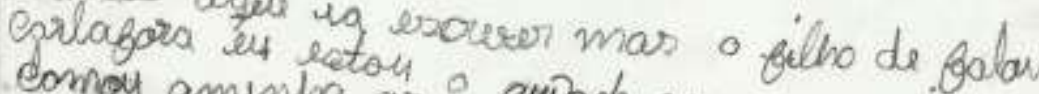

comou aminho arrori quad mas errapudinte papau vamas brim

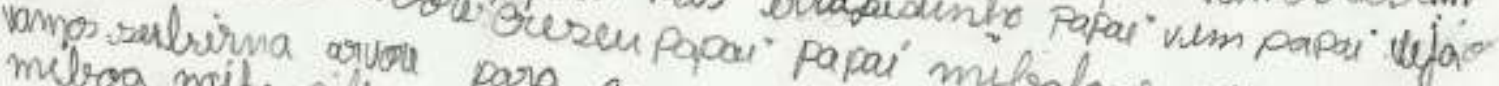

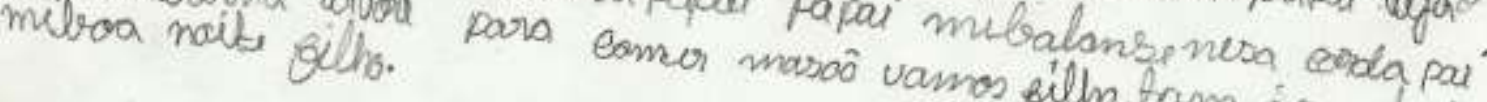
w ache qui in we de do
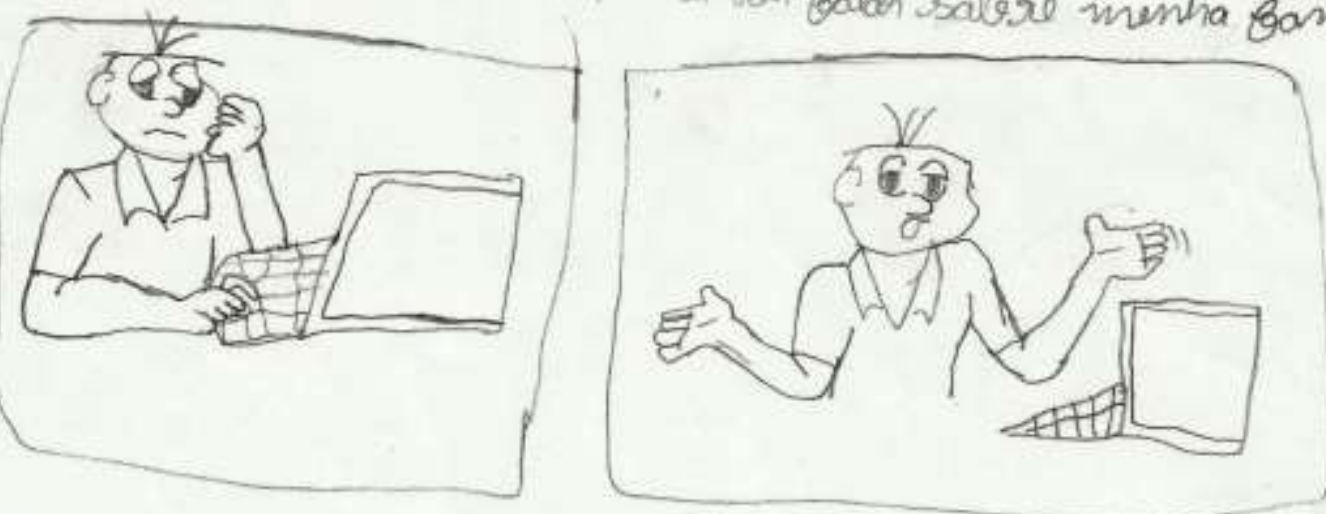

Cess: Deando

Fonte: Dados da Pesquisa. Teresina, 2013. 
Figura 8 - Produção de um aluno.

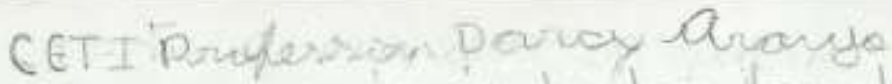

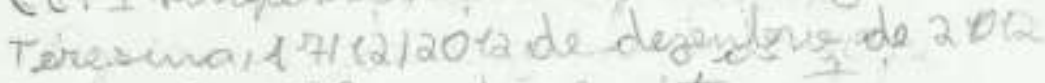

Dalssien alevs des souts

Hase do ensive bundamintal I

\section{En quero phero querwe}

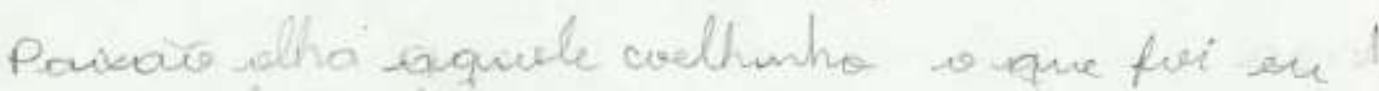

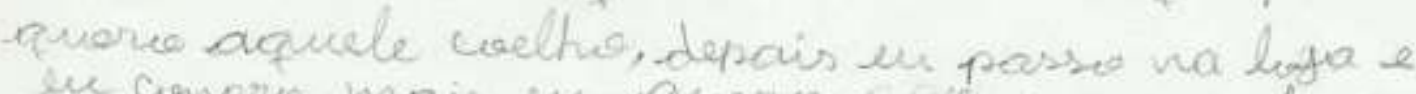

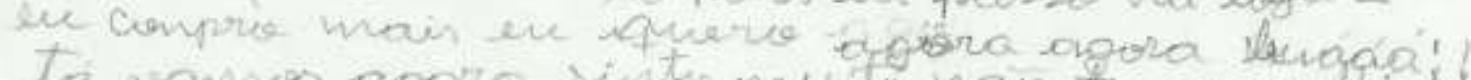

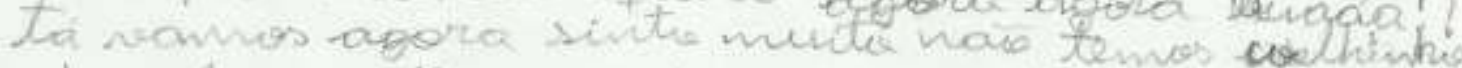

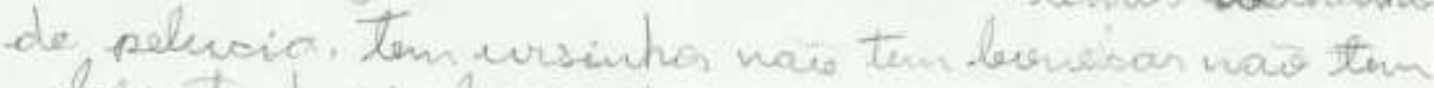

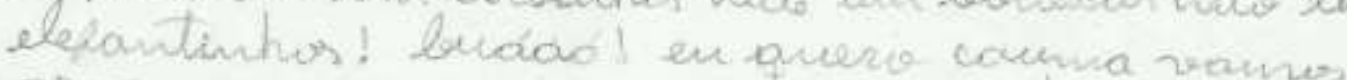

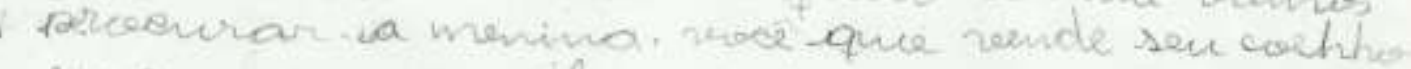
ere conpro pror milseais, dois mil, civar wil

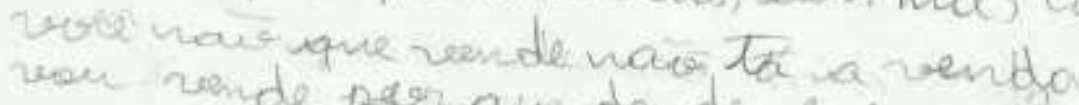

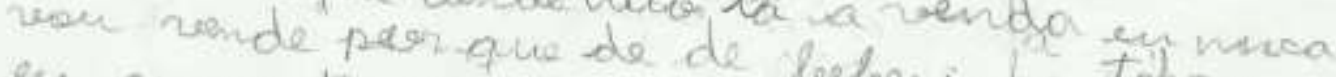

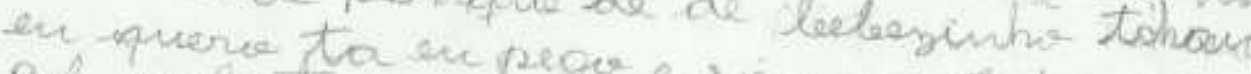

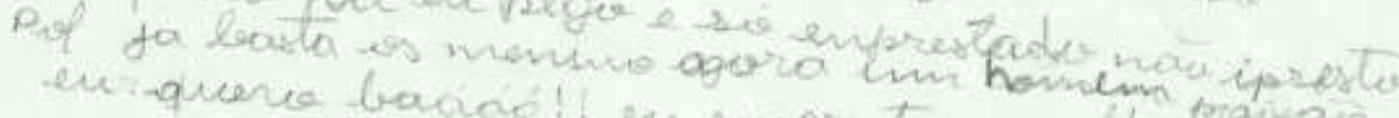

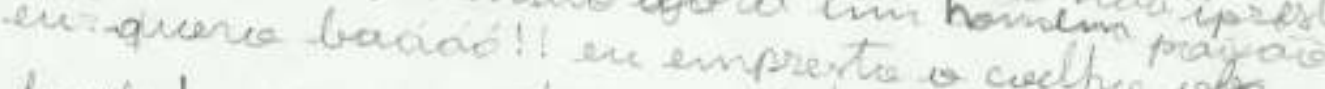
finerish a was gesto pega mai wiuc fin

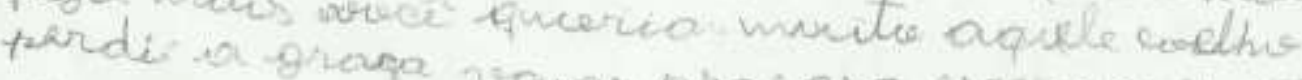

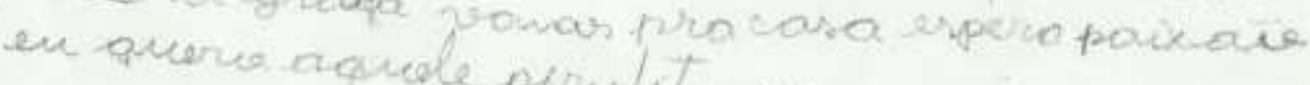
- perchle ue preerie.

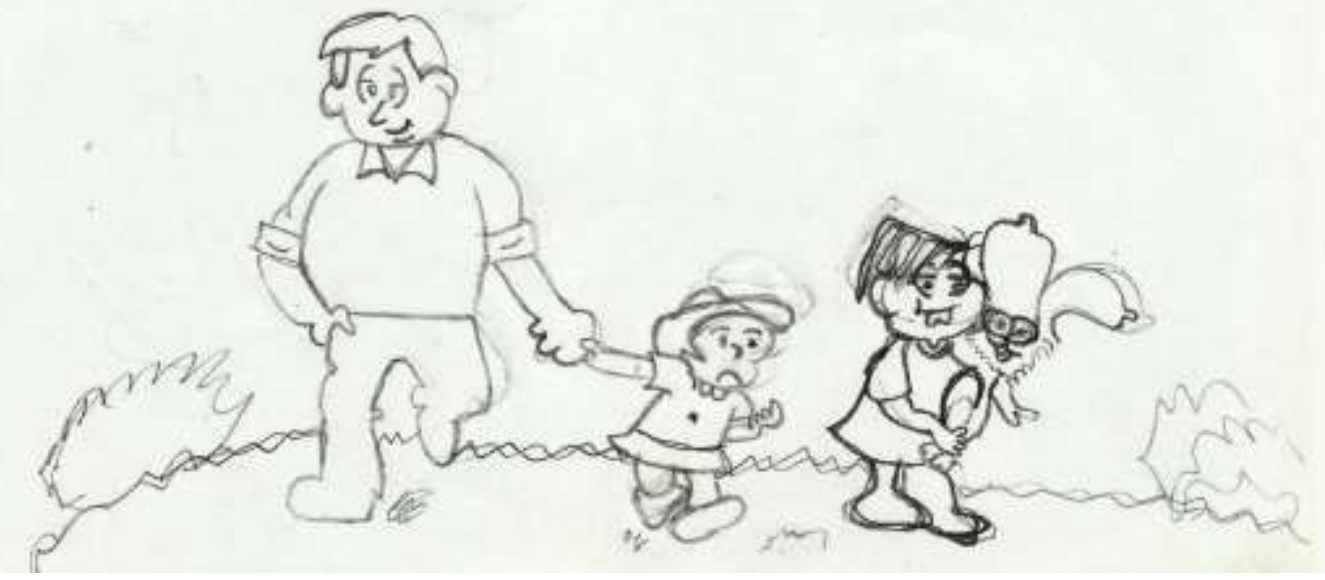

Fonte: Dados da Pesquisa. Teresina, 2013. 
No terceiro dia, reunimos os respectivos grupos para dramatizar com eles as histórias escolhidas, lidas no dia anterior. Sabemos que trazer para as aulas uma forma de expressar-se com o corpo também é uma maneira de trazer e adquirir mais aprendizados, pois é através do movimento corporal que a criança desenvolve a consciência do próprio corpo, da psicomotricidade possibilitando, também, trabalhar os seus aspectos afetivos, culturais e sociais.

No quarto dia, demos continuidade com os ensaios das histórias e organizamos o cenário das apresentações junto com os alunos para que pudessem aprender a trabalhar em grupo e para que participassem ativamente, estando presentes na construção de todo o trabalho realizado.

Por fim, os alunos realizaram a intervenção com as apresentações das histórias e nesse momento, pudemos observar que abandonaram a timidez para se expressar em público. Ao final, aprenderam a compreender e a interpretar textos em quadrinhos. Observamos, também, que proporcionamos aos professores uma ideia simples e prática de como trabalhar e utilizar em sala de aula as histórias em quadrinhos como um recurso metodológico.

Ressalte-se que cada fase, ou cada dia foi cuidadosamente planejado e avaliado, sendo seu feedback utilizado na redefinição das ações efetuadas.

\section{CONSIDERAÇÕES FINAIS}

Considerando a desmotivação dos alunos para a leitura e a escrita, desenvolvemos uma pesquisa-ação utilizando a ludicidade e as HQs no processo de ensino e aprendizagem. A problemática surgiu das observações efetuadas em sala de aula, uma vez que a observação é uma das técnicas de que o professor dispõe para melhor conhecer o comportamento de seus alunos, permitindo avaliar e diagnosticar, bem como identificar as dificuldades e avaliar desempenhos.

A pesquisa desenvolvida teve como objetivo proporcionar aos alunos do ensino fundamental de uma escola pública oportunidade de vivenciar a leitura e a escrita de forma prazerosa. No decorrer da prática interventiva, procuramos sempre envolver os alunos em cada etapa do projeto, a fim de que os mesmos participassem ativamente do processo de construção do conhecimento. Optamos por trabalhar com grupos e constatamos que esse aspecto é de grande relevância para a construção da autonomia do sujeito e sua socialização; pois os alunos 
aprendem a lidar com o diferente e com as mais variadas ideias, desenvolvendo o respeito pelo outro.

O desenvolvimento da investigação nos fez compreender que a importância e a necessidade do uso de uma metodologia de ensino diferenciada, que instigue o aluno a buscar o conhecimento. Neste aspecto, afirmamos que o uso das HQs em sala de aula, constitui-se uma rica experiência de leitura e de escrita que, além de contribuir no incentivo à prática de leitura, auxilia no processo educativo, por "obrigar" o leitor a pensar e a imaginar, desenvolvendo o seu pensamento lógico. Além disso, por ser um instrumento dinâmico, divertido, motiva o aluno e facilita a aprendizagem, apresenta-se como estratégia de leitura e de escrita, que supera a escrita mecânica de tarefas, oportunizando a criatividade e o desenvolvimento cognitivo, afetivo e psicomotor do aluno.

Portanto, esta pesquisa de caráter interventivo, provoca por um lado uma reflexão profunda as estratégias de ensino tradicionalmente utilizadas na escola, que tem contribuído para fragilizar o processo de ensino e aprendizagem da língua escrita. Por outro, nos aprendizes da docência, os monitores, a criatividade, imprescindível ao fazer pedagógico e preponderante no desenvolvimento da pesquisa.

\section{REFERÊNCIAS}

ANASTASIOU, Léa das Graças Camargos; ALVES, Leonir Pessates. Processos de ensinagem na universidade: pressupostos para as estratégias de trabalho em aula. Joinville: Univille, 2003.

BRASIL, Ministério da Educação e do Desporto. Secretaria de Educação Fundamental. Parâmetros Curriculares Nacionais: língua portuguesa. Brasília, 1997.

ENGEI, Guido Irineu. Pesquisa-ação. In.: Educar, Curitiba, n. 16, p. 181-191. 2000. Editora da UFPR. Disponível em http://www.educaremrevista.ufpr.br/arquivos_16/irineu_engel.pdf. Acesso em;. 23 jul. 2013.

FERREIRO, Emilia. (Org.). Os filhos do analfabetismo: propostas para alfabetização escolar na América Latina. Tradução de M. L. M. Abaurre. 3 ed. Porto Alegre: Artes Médicas, 1992.

FERREIRO, Emília; TEBEROSKY, Ana. Psicogênese da Língua Escrita. Porto Alegre, Artes Médicas, 1985. 
FRANÇA-CARVALHO, A. D.; MARTINS, C. H. R.; CONDE, E. P.; MONTEIRO, H. R. de S. (org.) Estratégias de ensino: propostas multidisciplinares de aprendizagens significativas. Teresina, EDUFPI, 2013.

FOUCAMBERT, J. A leitura em questão. Porto Alegre: Artes Médicas, 1994.

FREITAS, Eliana Sermidi de; SALVI, Rosana Figueiredo. A ludicidade e a aprendizagem significativa voltada para o ensino de geografia. Disponível em: http://www.gestaoescolar.diaadia.pr.gov.br/arquivos/File/producoes_pde/artigo_elian a_sermidi_freitas.pdf. UEL. 2007. Acesso em: 29 out. 2013.

LUYTEN, Sonia M. Bibe. História em quadrinhos: um recurso de aprendizagem. São Paulo: Ano XXI. Boletim 01. Abr., 2011.

MELO, Lavínia; XIMENES, Silva. Desenvolvimento, criatividade e aprendizagem: desafios ao educador/educadora da educação básica. Recife, 2007.

MINAYO, Maria Cecília de S. O desafio do conhecimento: pesquisa qualitativa em saúde. 5 ed. São Paulo: Hucitec, 2000.

NUNES, T. Leitura e escrita: Processos e desenvolvimento. In: E. S. de Alencar (org.), Novas contribuições da psicologia aos processos de ensino e aprendizagem. São Paulo: Cortez, 1992.

ORLANDI, Eni P. À flor da pele: indivíduo e sociedade. In: MARIANI, Bethania (org.) A escrita e os escritos: reflexões em análise do discurso e psicanálise. São Carlos: Claraluz, 2006.

OSÓRIO, L.C., in Psicologia Grupal: uma nova disciplina pra o advento de uma era. Porto Alegre: Artmed, 2003.

SILVA, Ezequiel Theodoro. Leitura na escola e na biblioteca. 4. ed. São Paulo: Papirus, 1993.

SPERONI, K. S. Reflexões a cerca do processo de leitura e escrita: compreender para transformar o ensino. P@rtes.V.00 p.eletrônica. Julho, 2010. Disponível em <www.partes.com.br/educacao/processodeleituraeescrita.asp >. Acesso em: 28 out. 2013.

TEBEROSKY, Ana. Aprendendo a escrever: Perspectivas psicológicas e implicações educacionais. Trad. Cláudia Schilling. Barcelona: Horsori, 1992.

TORRE, Saturino de la. Dialogando com a Criatividade - da identificação à criatividade paradoxal. São Paulo: Mardras, 2005. 